\title{
SYNERGETIC MODELING OF THE TRANSPORTATION PROCESS IN THE CENTERS
}

(C)Abdullayev A., Andijan Institute of Mechanical Engineering, Andijan,Uzbekistan, alimardon abdullayev89@mail.ru

(CGaffarov M., Andijan Institute of Mechanical Engineering, Andijan, Uzbekistan, gaffarov1965@inbox.ru

\section{СИНЕРГЕТИЧЕСКОЕ МОДЕЛИРОВАНИЕ ПРОЦЕССА ПЕРЕВОЗКИ В ЦЕНТРАХ}

(САбдуллаев А. И., Андижанский машиностроительный институт, 2. Андижан, Узбекистан, alimardon abdullayev89@mail.ru

(ГГаффаров М. Т., Андижанский машиностроительный институт, 2. Андижан, Узбекистан, gaffarov1965@inbox.ru

Abstract. The functioning of the transport system of the logistics center based on synergetic methods is investigating. The main provisions of synergetic useful for organizing the work of logistics centers are outlining. A model has been built to study the transportation process and the control parameter interval has been found to ensure the stable functioning of the transport network of the logistics center.

Аннотаџия. Исследована функционирование транспортной системы центра логистики на основе методов синергетики. Изложены основные положения синергетики полезные для организации работ центров логистики. Построена модель для изучения процесса перевозки и найден интервал управляющего параметра для обеспечения устойчивого функционирования транспортной сети центра логистики.

Keywords: logistics, self-organization, synergetic.

Ключевые слова: логистика, самоорганизация, синергетика.

Synergetic is an interdisciplinary area of scientific research, the task of which is to study natural phenomena and processes based on the principles of self-organization of systems (consisting of subsystems) [1]. The methodological approach of synergetic is to talk about common interests and mathematical methods for studying related nonlinear phenomena in different fields of science based on the study of complex phenomena of self-organization [2]. In this paper, based on the methods of synergetic, a new approach to the study of some logistics problems is developed [3].

One of the main tasks of logistics is the organization of transportation. The solution to this problem should be carried out by ensuring the safe and timely delivery of various goods to their destination. Synergetic provides the principles and laws of the coordinated interaction of various parts of a complex system in their oppositions to dissipative destruction, on the interaction leading to the spontaneous occurrence of systemic effects of a spatial and temporary nature.

If we consider the transportation process from the standpoint of synergetic, then the problem arises of its organization by studying all the factors influencing it. Loading and unloading time, travel time, characteristics of the roadmap topology, technical condition of transport and cargo, etc. Synergetic methods allow, from the set of factors influencing the process, to single out the main ones that determine the spontaneous regulation of the transportation process. The combination of 
factors characterizing the state of the transportation process according to synergetic is called the order parameter. Having determined the other parameter, it is possible to regulate the transportation process so that all the characteristics will act in concert, which ensures a stable dynamic mode of operation of the logistics centre, through self-organization of its various functional parts.

Self-organization - in the most general sense means self-movement, spontaneous structuring of the system and processes.

The idea of self-organization is the disciplinary direction in mode a categorically intern science, seeking the unity of all phenomena and processes.

The main conditions of self-organization are considered 1) a significant remoteness of the system from equilibrium, which is enslured by its openness; 2) the openness of the system in our case means a constant inflow and outflow of cargo and information; 3) non-linear interaction between the various functional parts of the system.

The origins of synergetic. At the end of the 20th century, a new science arose. Herman Harken (Germany, Stuttgart) called this science Synergetic.

She studies the laws and principles of the combined action of complex systems. The human body as a complex system is controlled independently according to the laws of synergetic. A complex network of logistics centres can also be considered from the standpoint of synergetic in order to organize a qualitatively new state of their functioning.

If synergy in biology is understood as the joint and homogeneous functioning of organs (for example, muscles) or systems, then in a complex system of a network of logistics centres, these are many characteristics of the interaction between the various functional structures of the centres.

If synergy in medicine is understood as the combined effect of medicinal substances on the body, in which the cumulative effect exceeds the effect exerted by each component individually, then in logistics, synergism is carried out by coordinating various characteristic times of the functioning of transportation processes.

Synergetic logistics is anew area of research of the land transportation system in our republic. It is necessary to create training programs in this direction, aimed at training new personnel professionally knowledgeable in engineering synergetic methods and successfully using them in the practice of logistics centers. Today, precisely, the synergetic methodology allows us to create a conceptual basis for logistics and make a breakthrough in this area.

Human health is determined by the concerted action of all parts of a person. To study, for example, physiological processes according to the method of synergetic modelling, it is necessary to find the so-called order parameter of the system under study. Heart rhythm is a parameter of the order of the cardiovascular system. Therefore, the main task of medical engineers is to develop new medical technologies for the analysis of complex dynamic parts of the whole organism. In the first approximation in synergetic logistics, the following characteristics of the transportation process should be taken into account.

-The share of the safely delivered cargo to the destination is accepted as an order parameter.

-The control parameter includes the time of cargo delivery as a measure of the transport system of the logistics centre.

-The figure shows a general topological model of the transportation process.

The figure shows a general topologic model of the transportation process. 


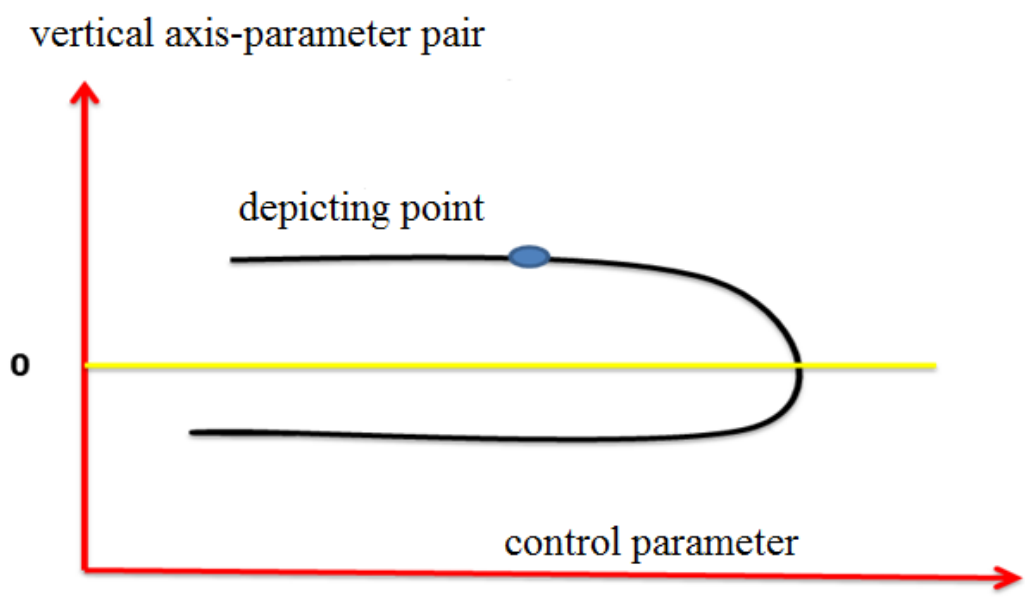

Figure. General topological model

In this figure, the transport process is described by a parabolic curve. The coordinates of the image point on it characterize the state of transportation. When the control parameter changes, this point shifts along a parabolic trajectory.

As can be seen from this figure, as the value of the control parameter increases, the point shifts to the right, which is accompanied by a decrease in the value of the order parameter. Upon reaching the zero value of the order parameter, the system is destroyed i.e. in our case, the centre of Logistics ceases to function.

\section{Conclusion}

Application of synergetic methods to solving some problems of the transportation process allows us to find the main characteristics of the stable functioning of the logistics centres and the transport system. It is shown that the share of successfully cargo delivery critically depends on the ratio of the characteristic timed of the functioning of the centre's transport system.

\section{References:}

1. Haken, H. (1987). Synergetics. In Self-Organizing Systems (pp. 417-434). Springer, Boston, MA. https://doi.org/10.1007/978-1-4613-0883-6_22

2. Zainabidinov, C, Askarov, B. L, \& Ivanov, N. Y. 2019. Vibrant Interpretation and nonlinear kinetics of self-organization processes in nan systems. Bulletin of the ADU, 14-20. (in Russian).

3. Abdullayev, A. (2019). Tasks of the transportation of goods and the organization of logistics centers. (in Russian).

4. Tret'yakova, A. P., \& Zykov, O. A. (2010). Logistika. Tyumen'. (in Russian).

5. Gadzhinskii, A. M. (1999). Logistika. Moscow. (in Russian).

6. Levkin, G. G. (2009). Logistika: teoriya i praktika. Rostov on Don. (in Russian).

7. Mirotin, L. B. (2002). Transportnaya logistika. Moscow. (in Russian).

8. Lukinskii, V. S. (2007). Model' i metodistskaya teoriya logista. St. Petersburg. (in Russian).

9. Lavrikov, I. N., \& Penshin, N. V. (2016). Transportnaya logistika. Tyumen'. (in Russian).

10. Dybskaya, V. V., Zaitsev, E. I., Sergeev, V. I., \& Sterlikova, A. N. (2011). Logistika. Integratsiya i optimizatsiya logisticheskikh protsessov v protsesse. Moscow. (in Russian). 


\section{Список литературы:}

1. Haken H. Synergetics // Self-Organizing Systems. Springer, Boston, MA, 1987. P. 417-434. https://doi.org/10.1007/978-1-4613-0883-6_22

2. Zainabidinov C, Askarov B.L, Ivanov N. Y. Vibrant Interpretation and nonlinear kinetics of self-organization processes in nan systems // Bulletin of the ADU. 2019. P. 14-20.

3. Abdullayev A. Tasks of the transportation of goods and the organization of logistics centers, 2019.

4. Третьякова А. П., Зыков О. А. Логистика. Тюмень. 2010.

5. Гаджинский А. М. Логистика. М. 1999.

6. Левкин Г. Г. Логистика: теория и практика. Ростов на/Д. 2009.

7. Миротин Л. Б. Транспортная логистика. М. 2002.

8. Лукинский В. С. Модель и методистская теория логиста. СПб. 2007.

9. Лавриков И. Н., Пеншин Н. В. Транспортная логистика. Тюмень. 2016.

10. Дыбская В. В., Зайцев Е. И., Сергеев В. И., Стерликова А. Н. Логистика. Интеграция и оптимизация логистических процессов в процессе. М. 2011.

Работа поступила

в редакциию 14.02.2020 2.
Принята к публикащчи

19.02.2020 2

Ссылка для циитирования:

Abdullayev A., Gaffarov M. Synergetic Modeling of the Transportation Process in the Centers // Бюллетень науки и практики. 2020. Т. 6. №3. С. 275-278. https://doi.org/10.33619/2414$2948 / 52 / 32$

Cite as $(A P A)$ :

Abdullayev, A., \& Gaffarov, M. (2020). Synergetic Modeling of the Transportation Process in the Centers. Bulletin of Science and Practice, 6(3), 275-278. https://doi.org/10.33619/2414$2948 / 52 / 32$ 